\title{
Katolícka literárna kritika v rokoch 1945 - 1948
}

\section{Edita Príhodová}

\author{
PRÍHODOVÁ, E.: Catholic Literary Criticism in 1945 - 1948 \\ SLOVENSKÁ LITERATÚRA, vol. 68, 2021, no. 5, pp. 495-513 \\ DOI: https://doi.org/10.31577/slovlit.2021.68.5.2 \\ ORCID ID: 0000-0002-2255-0850
}

Key words: Nová práca magazine, Verbum magazine, Aloš Stankovský, Vojtech Mihálik, Jozef Kútnik Šmálov, Laco Gejza Fagul'a

\begin{abstract}
The article provides an insight into the writings of Slovak Catholic literati published between the end of World War II and the establishment of the communist totalitarian rule in Czechoslovakia in 1948. The writing of Catholic literary critics concentrated in two religious-cultural periodicals Nová práca and Verbum. For both magazines, the article draws on their respective historical-contextual backgrounds and points to differences in their visions of cultural work. Subsequently, it characterises the way the periodicals profiled their literary criticism in reviews, glosses, commentaries and articles dealing with more general cultural topics and provides profiles of the three most significant literary critics - Aloš Stankovský (1925-2002), Vojtech Mihálik (1926 - 2001) and Jozef Kútnik Šmálov (1912 - 1982). The article is a contribution towards a better knowledge of the Catholic literary criticism that formed alongside the poetry of Slovak Catholic Modernists. The work of Catholic literary criticism has not been studied as much as the poetry of Catholic Modernists and this article aims at rectifying this deficiency somewhat.
\end{abstract}

Klúčcové slová: časopis Nová práca, časopis Verbum, Aloš Stankovský, Vojtech Mihálik, Jozef Kútnik Šmálov, Laco Gejza Fagul'a 
ndrej Mráz v Dejinách slovenskej literatúry z roku 1948 sumarizoval povojnovú aktivitu katolíckych literátov takto: „V posledných rokoch v samostatnú skupinu čoraz programovitejšie zoskupujú sa katolícki spisovatelia, ktorí nateraz disponujú dvoma literárnymi časopismi, a to Novou prácou a Verbumom " (Mráz 1948: 292). Pri výskume katolíckej literárnej kritiky možno prirodzene predpokladat', že sa profilovala na stránkach oboch katolíckych kultúrnych periodík, ktoré literárny historik zaregistroval ako literárne centrá s určitým programom. Tieto katolícke kultúrne časopisy svedčia o tom, že katolícka cirkev na Slovensku si po skončení druhej svetovej vojny nezvolila defenzívnu taktiku pasívneho odporu ani stiahnutia sa z verejného priestoru. ${ }^{2}$ Po oslabení katolíckej elity odchodom katolíckych literátov do emigrácie sústred'ovali povojnové časopisy nanovo svoj domáci tvorivý potenciál a iniciovali spoluprácu s mladou generáciou katolíckych intelektuálov, ktorým poskytovali publikačné možnosti (Katuninec 2005:307).

Samotný pojem katolícka literárna kritika sa môže javit' ako nečistý, neliterárny, podobne ako negatívnym konotáciám dlho vzdorujúci už zaužívanejší literárny termín katolícka moderna. Pri špecifikácii obsahu pojmu môžu byt' východiskom výskumy Martina C. Putnu o českej katolíckej literatúre v európskom kontexte, ktorý predpokladá, že katolícka literatúra sa zrodila z ducha sekularizácie, ked' cirkev stratila svoje výsostné postavenie v duchovnej, kultúrnej aj intelektuálnej oblasti a stala sa iba jednou zo súčastí moderného sveta. Špecifickú katolícku literatúru potom možno odlíšit od „literatúry vôbec“: katolícka literatúra je podla M. C. Putnu literatúrou katolíkov ako vyhranenej menšiny uprostred sekulárneho sveta (Putna 1998: 35).V nadväznosti na takéto chápanie zahŕňa pojem katolícka literárna kritika tvorcov, ktorí sa zasadzovali nielen za hodnotový vplyv katolíckej cirkvi na kultúru, ale zaoberali sa aj reflexiou katolíckej literatúry, čo prirodzene nevylučuje záujem o literatúru ako takú. Možno tiež odlísit' katolíckych literátov od autorov-katolíkov, ktorých tvorivé ambície sa neupínali na kultúrne projekty katolíckej cirkvi, ale prioritne na národnú literatúru a kultúru (v slovenskom prostredí to boli v danom čase napríklad Milo Urban či Valentín Beniak).

\section{Časopis pre katolícku inteligenciu Nová práca}

Časopis Nová práca s podtitulom Revue pre kultúrny, náboženský a sociálny život, vydávaný Spolkom svätého Vojtecha v Trnave, nadväzoval na predchádzajúci kultúrno-náboženský katolícky časopis Kultúra (1926 - 1944) od rovnakého vydavatel'a. Nová práca začala vychádzat' v septembri 1945 hned' po usporiadaní vzt'ahu československej vlády a cirkví. Ked'že Spolok svätého Vojtecha predstavoval celonárodnú nábožensko-kultúrnu inštitúciu katolíckej cirkvi na Slovensku, časopis bol oficiálnym prejavom záujmu katolíckej cirkvi o povojnovú slovenskú kultúru. Finančne ho podporoval biskupský zbor. Menovaným šéfredaktorom

1 V príspevku nadväzujem na svoje predchádzajúce výskumy tejto témy (Príhodová 2016, Príhodová 2020). Vychádzam zo všeobecnej charakteristiky katolíckych kultúrnych časopisov a zameriavam sa na literárnu kritiku, ktorá sa v nich profilovala.

2 V roku 1946 uverejnil Alexander Matuška v časopise Elán článok, v ktorom neuspokojivú literárnu situáciu po vojne nepripísal ani tak katolíckym literátom - emigrantom, ale rezistencii tých, čo ostali. To, že nepublikovali, pramenilo podl'a Matušku ,v túžbe povedat' režimu čím viac neprijemností, obvinit' ho aj z toho, za čo naozaj nemôže“. Podl'a neho sú takí, čo „nepíšu a mohli by (Silan, Hlbina atd'.)“ (Matuška 1956: 165). 
a obsahovým garantom časopisu bol vždy kňaz, v rokoch 1945-1947 to bol mon-

signor Augustín Raška, od októbra 1947 do februára 1948 monsignor Pavol Macháček. Kňazi zastrešovali svojím menom časopis ako fórum katolíckej cirkvi, no do konkrétnej redakčnej práce, zvlášt v oblasti kultúry, príliš nezasahovali. Ovel'a agilnejší boli laickí (nekňazskí) spolupracovníci, ktorí patrili do redakčného kruhu: Aloš Stankovský a Laco Gejza Fagul'a.

Redaktori dbali na to, že Nová práca je nepolitický časopis s prioritou vyjadrovat' sa k aktuálnym otázkam, ktoré hýbali dobovou spoločnost'ou. Takáto orientácia vyžadovala od redaktorov na jednej strane solídne vedomosti o katolíckej sociálnej náuke, ale aj povedomie o takých spoločenskovedných odboroch, akými boli sociológia, politológia, filozofia etiky, štátu a práva. Práve články so sociálno-krestanskou tematikou patrili v dobovom kontexte medzi najprínosnejšie, a to pre spôsob spracovania témy, ked'že sa opierali o evanjelium a sociálne encykliky. Poukazovali na zjednodušenia dobovej politickej rétoriky (napríklad idealizáciu či absolutizáciu ludu), politické riziká (koncentrácia moci štátom) a ponúkali alternatívne pohl'ady, uvedomujúc si nedostatky nielen komunistickej, ale aj liberálnej (kapitalistickej) spoločnosti (A. P. 1946: 61).

Revue bola napojená na európsky kultúrny katolícky prúd, nadväzovala na zahraničné, najmä francúzske filozofické, teologické a kultúrne podnety (George André, Étienne Gilson, Henri de Lubac, Louis Chaigne, Guy Chastel, Francis Jammes, Charles Péguy, Paul Claudel, Léon Boy, François Mauriac). Kultúrny rozmer časopisu napíňali články s dôrazom na prínos krestanstva do duchovnej kultúry (kostoly, benediktínske duchovné spevy, mariánske motívy v slovenskej literatúre), akcentovanie osobností, ktoré sa stávali symbolmi spojenia katolicizmu a práce pre národ (František Richard Osvald, Andrej Radlinský, Štefan Moyzes, svätý Vojtech, bernolákovci), literárne príspevky a tiež glosy z iných druhov umenia, najmä z hudby, divadla a filmu.

Časopis mal bohatý okruh prispievatel'ov z mladej (povojnovej) i zo strednej generácie, a to predovšetkým vd'aka agilnosti redaktorov, ktorí viedli bohatú korešpondenciu s autormi, oslovovali potenciálnych prispievatel'ov, spolky aj vydavatel'stvá doma i v zahraničí, žiaden list nenechávali bez odpovede a žiaden rukopis bez spätnej väzby. Na prispievatel'ov mohlo motivačne pôsobit' aj to, že publikované rukopisy boli vcelku slušne honorované, štandardne sto korún na stranu, mesačný paušál výdavkov pre prispievatel'ov predstavoval 7500 korún. Ako možno odčítat' z listu mladého študenta Miroslava Válka, finančný benefit nebol jediným dôvodom, prečo prispievat' do tohto periodika: „Nová práca stáva sa centrom kultúrneho snaženia slovenských katolíkov, do ktorého chcem sai ja podl'a svojich možností zapojit."“3

Nová práca si postupne získavala renomé, ktoré pritiahlo mladých, ale aj skúsených, dokonca tiež nekatolíckych i zahraničných prispievatelov (napríklad Emila Boleslava Lukáča, Jozefa Vašicu, Jaroslava Durycha, Jacquesa Hérissaya alebo Johana Huizingu), z ktorých mnohí sa po zániku časopisu presadili vo sfére sekulárnej slovenskej kultúry. Ako recenzenti sa tu profilovali napríklad Ján Sedlák a Jozef Butvin, Imrich Kotvan ako autor literárnohistorických príspevkov

3 Spolok svätého Vojtecha v Trnave, Archív SSV, fond Nová práca: List Miroslava Válka redaktorovi NP. Signatúra Scr XIII č.1/430 b, 28. máj 1946. 
498 a Ján Horecký ako autor lingvistických článkov. Redakcia mala externých spolupracovníkov v zahraničí (v Európe najmä v Taliansku, vo Francúzsku a v Pol'sku, tiež v Spojených štátoch amerických a Kanade), ktorí ich upozorňovali na kvalitné zahraničné časopisy, vyhl'adávali potenciálnych autorov a v mene redakcie ich oslovovali na spoluprácu.

Postupné zosilňovanie politickej moci komunistickou stranou (bližšie Marsina a kolektív 1992: 265-267) sa negatívne prenášalo aj do kultúrnej sféry. Na prelome rokov 1946/1947 hrozilo, že Nová práca i druhý katolícky kultúrny časopis Verbum budú zakázané. ${ }^{4}$ Povereníctvo informácií ako politický orgán, pod ktorý patrili aj tlačové médiá, vyvíjalo na redaktorov časopisov mocenský nátlak, aby neplnili jednu zo svojich základných spoločenských úloh - verejnú kontrolu a kritiku štátnej moci. Zo zachovanej korešpondencie redaktorov Novej práce s prispievatel'mi je zjavné, že redakcia sa nevzdala zámeru prinášat články vyjadrujúce sa k náboženským, k sociálnym a ku kultúrnym témam z katolíckeho stanoviska, avšak zároveň úzkostlivo rešpektovala požiadavky povereníctva. Redaktori upozorňovali prispievatel'ov, že môžu „komentovat' určité problémy verejného života zo stanoviska katolíckeho, ale formou naskrz decentnou a odosobnenou“. 5 Mnoho kvalitných príspevkov, ktoré by v demokratickom spoločenskom ovzduší boli akceptované, odmietali: „Veladôstojný pane, pomery sa vel'mi zmenili, a aby sme sa vyhli akýmkol'vek nedorozumeniam s úradmi v záujme NP, nášho spolku a Vás samotného, musím odhliadnut' od uverejnenia zaslaných príspevkov. Pokúšal som sa škrtat', ale sa mi to nepodarilo. Azda len článok Optimizmus mladých vyjde, ale nie v marcovom čísle, lebo ono je už preplnené.“6 Redaktor L. G. Fagul'a, ktorý sa ešte v roku 1946 všetkými dostupnými prostriedkami zasadzoval za spoluprácu s francúzskym spolkom katolíckej literatúry a sám francúzsku literatúru prekladal, sa dostal do dilemy, či by d'alším prekladaním ,azda nenarazili na dnešok, čo by sme pravda rozhodne nechceli. [...] Budeme musiet' hodne popustit' z citovania francúzskej katolíckej literatúry, hoci sme sa vždy držali len viery a nikdy nie politiky".?

Je očividné, že politická situácia v štáte na prelome rokov 1947/1948 sa negatívne podpisovala na kultúrnom živote. $V$ časopise pribúdali príspevky signované iba iniciálami, čo naznačuje, že politické udalosti skutočne vyvolávali $\mathrm{v}$ občanoch pocit strachu. Napriek opatrnosti redakcie, ktorá sa snažila naklonit' si štátne orgány, aby Novú prácu nad'alej dovolili vydávat', časopis ako súčast' Spolku svätého Vojtecha sa postavil v otázke vzt'ahu k režimu a štátu oficiálne

4 „V minulých dňoch som sa dozvedel, že Verbum nateraz vychádzat' nebude. Iste teda máte viac času, ked' Vám starosti s Vašou revue odpadli,“ napísal redaktor Novej práce A. Stankovský Jozefovi Kútnikovi Šmálovovi, redaktorovi Verbumu (Spolok svätého Vojtecha v Trnave, Archív SSV, fond Nová práca: List Aloša Stankovského Jozefovi Kútnikovi Šmálovovi. Signatúra Scr XIII č. 1/178, 19. októbra 1946). O niekol'ko mesiacov neskôr sa Ignác Gašparec redaktora Novej práce pýtal, či „bude NP vychodit' aj v tomto roku, lebo tu počut' všelijaké chýry, že ju zakázali“ (Spolok svätého Vojtecha v Trnave, Archív SSV, fond Nová práca: List Ignáca Gašparca redaktorovi Novej práce. Signatúra Scr XIII č. 1/291, 13. január 1947). 5 Spolok svätého Vojtecha v Trnave, Archív SSV, fond Nová práca: List redaktora Jozefovi Patúcovi. Signatúra Scr XIII č. 1/210 b, 29. november 1947.

6 Spolok svätého Vojtecha v Trnave, Archív SSV, fond Nová práca: List redaktora Jozefovi Klučárovi. Signatúra Scr XIII č. 3d/721b 4, február 1948.

7 Spolok svätého Vojtecha v Trnave, Archív SSV, fond Nová práca: List Laca Gejzu Fagulu Jozefovi Mitošinkovi. Signatúra Scr XIII č. 3d/741a, 10. marec 1948. 
za stanovisko biskupského zboru. Dôsledkom bolo definitívne zastavenie jeho 499 vydávania vo februári 1948. Neprišla už ani pomoc, ktorú Spolok svätého Vojtecha žiadal pre d'alšie vydávanie Novej práce od Ústrednej katolíckej kancelárie v Bratislave, ked'že aj jej činnost' bola napriek protestom biskupov násilne zastavená v novembri 1948, s odvolaním sa na „verejný záujem“ (Vaško 1990: 54). V poslednom čísle časopisu redakcia neuverejnila žiadne stanovisko, ktorým by zdôvodnila zastavenie jeho vydávania, nanajvýš autor nepodpísaného príspevku akoby kronikársky poznamenal: „Anno Domini 1948, ked' bol mier a mier nebol, ked'sa st'ahovali mračná na búrku a svet ubolený, hladný, chudobný, chorý a bojazlivý čakal, čo z toho všetkého len bude“ (Mládež debatuje 1948:117). Ukončenie vydávania Novej práce „bolo odôvodňované vnútornými kolíziami katolíckej inteligencie" (Katuninec 2005: 313). Zachované dokumenty však hovoria o nečakanom úradnom zastavení príprav marcového čísla (čo potvrdzuje redakčná korešpondencia), ${ }^{8}$ o vízii d'alších čísel (Redakcia 1948: 2), vydávaní časopisu ${ }^{9}$ aj strate nádeje, že niekedy bude obnovený. ${ }^{10}$

\section{Profilácia literárnej zložky a literárna kritika v časopise Nová práca}

Z literárnych rubrík Novej práce možno odčítat' viaceré funkcie. Vzhl'adom na dobový kontext smerujúci k politizácii bol časopis tribúnou polemických reakcií na zväzujúci tlak na kultúru. Redakcia sa napríklad ohradila proti zriadeniu takzvanej publikačnej komisie, ktorá bola politickou štruktúrou a znamenala cenzúru kultúry (St. S 1947). Ďalším príkladom je reakcia redakcie na iniciatívu Jozefa Felixa otvorit' diskusiu o mieste takzvaných spisovatel'ov kolaborantov (Mila Urbana, Jozefa Cígera Hronského, Rudolfa Dilonga a Tida J. Gašpara) v dejinách slovenskej literatúry: Felixovo stanovisko vtedy odmietla s odôvodnením, že dejiny slovenskej literatúry by neboli bez týchto mien objektívne (Šteblík 1947: 122).

Každé číslo malo bohatú recenznú rubriku, pričom hlavnú čast' recenzovaných titulov predstavovali knihy vydané Spolkom svätého Vojtecha. Literárna kritika v Novej práci sa identifikovala so špecifickou funkciou skúmat' všetky diela katolíckych autorov bez rozdielu, či majú umeleckú alebo primárne náboženskú funkciu. Napriek tomuto faktu redaktori Novej práce tvrdili, že súveká náboženská produkcia spolku nie je ludová, ale patrí ku „katolíckej klasike“ a spolok si vyberá z literatúry umelecky hodnotné tituly katolíckych autorov zo zahraničia.

Z literárnohistorického hl'adiska je dôležité, že povojnová Nová práca pomáhala etablovat' literárnohistorický termín katolícka moderna. Redaktori boli presvedčení o opodstatnenosti tohto termínu, akokolvek bol problematický pre samotných básnikov, ktorí ním boli označovaní od tridsiatych rokov 20.

8 Spolok svätého Vojtecha v Trnave, Archív SSV, fond Nová práca: List redaktora Ernestovi Zavarskému. Signatúra Scr XIII č. 3d/803c, 21. február 1948.

9 Dokumenty o priamom zákaze vydávania časopisu sa v archíve nezachovali. K dispozícii sú sekundárne zdroje, napríklad list redakcie Ernestovi Zavarskému z 2. apríla 1948, v ktorom redaktor píše o zastavení vydávania Novej práce s nádejou, že možno nejde o trvalé rozhodnutie politických orgánov (Spolok svätého Vojtecha v Trnave, Archív SSV, fond Nová práca: List redaktora Ernestovi Zavarskému. Signatúra Scr XIII č. 3d/802a, 2. apríl 1948).

10 „Milý pán kolega, asi už viete, že NP zastavili. Či to bude trvalé, alebo sa nám podarí vymôct' d'alšie vychádzanie, predbežne nevieme... Myslím, potrebné bude podat' quasi žiadost' na Správu SSV“ (Spolok svätého Vojtecha v Trnave, Archív SSV, fond Nová práca: List redaktora Ernestovi Zavarskému. Signatúra Scr XIII č. 3d/802a, 2. apríl 1948). 
500 svätého Vojtecha presadzoval realizmus vydávaním prekladov realistickej tvorby, predovšetkým ruskej a francúzskej. K tomuto štýlu inklinovali aj spolupracujúci recenzenti časopisu, ked'že v ich zábere boli najmä preklady realistických románov. Explicitne to vyjadril Vojtech Mihálik v článku o súčasnej slovenskej próze: „obdobie literárneho realizmu nebolo v našej próze dostatočne tvorivo využité; vel'mi sme sa náhlili za ostatným svetom a vypomstilo sa to" (Mihálik 1947c: 422). Francúzsky a ruský realizmus vysoko hodnotil aj J. Butvin, v časopise publikujúci pod autorskou značkou fn. $\mathrm{V}$ recenzii na román Henryho Bourdeauxa Roquevillardovci však vítal akýsi typ krestanského realizmu, ktorý reprezentoval Francúz Felix Timmermans, pretože klasický, laický realizmus preferuje podla neho negatívne ukončenie s katastrofickým záverom, čo považoval za schému (Butvin 1946). Zdá sa, že Spolok svätého Vojtecha nepresadzoval realizmus iba z dôvodu štýlovej ústretovosti voči čitatel'om, ale tiež preto, že v zahraničnej literatúre, najmä francúzskej a anglickej, boli katolícki autori mimoriadne produktívni v realistickej románovej tvorbe, na základe čoho sa termín katolícky román dokonca literárnohistoricky etabloval (Herissay 1947).

Poéziu a prózu publikovali v Novej práci Pavol Hrtus Jurina, Svetloslav Veigl, Pavol Gašparovič Hlbina, J. Motulko, Pavol Strauss a J. Haranta. Z hl'adiska povojnového vývinu katolíckej moderny je významné júnové číslo z roku 1947. Prinieslo prepis prednášok o poézii J. Harantu, J. Silana a J. Motulka, ktoré odzneli na večierku katolíckej poézie 8. mája 1947 v Bratislave pri príležitosti vydania troch nových básnických zbierok týchto autorov vo vydavatel'stve Verbum. ${ }^{11} \mathrm{Z}$ nových mien na stránkach časopisu zaujali Stanislav Šmatlák, Zlata Dônčová, A. Stankovský, Ján Frátrik, Julo Zborovian, Severín Zrubec, Gorazd Zvonický. Medzi „nádeje katolíckej poézie“ boli zaradení Viliam Turčány, V. Mihálik, M. Válek a Juraj Pado (Nádeje katolíckej poézie 1947).

V. Mihálik, vtedajší poslucháč filozofie na Slovenskej univerzite v Bratislave, pravidelne prispieval do Novej práce básňami so spirituálnym a s osobným akcentom (jeho knižnú prvotinu Anjeli vydal Spolok svätého Vojtecha v roku 1947). V časopise sa osvedčil ako básnik aj recenzent, autor článkov o súčasnej slovenskej literatúre, prekladatel' a posudzovatel' rukopisov. Zapojil sa tiež do „polemiky o anjelské zeme“ (Miko 1978; Bílik 2013), kde sa zastával J. Felixa (Felix 1946), o ktorého postoj sa neskrývane argumentačne opieral. Pritom však presvedčivo formuloval vlastné stanoviská, vychádzajúc z interpretácií diel J. C. Hronského, Dominika Tatarku, Františka Švantnera a Jozefa Horáka, ktorými Felixovu kritiku precizoval. Lyrizáciu v próze považoval za literátske klišé, ktoré je „vari ešte dedičstvo romantizmu“ (Mihálik 1947c: 418). Prekážali mu „papierové mená“, exaltovaná

11 J. Haranta: V najkrajšej domovine, J. Silan: Piesne zo Ždiaru, J. Motulko: V mimózach vietor 
reč postáv, presahujúca „hranicu uveritel'nosti“ (Mihálik 1947c: 419), nefunkčné detaily a príliš výrazné stotožnenie hrdinu a autora. $V$ posudzovaní lyrizovanej prózy bol pre neho rozhodujúci „d'aleký a nepresvedčivý postoj k životu“, ktorý „spôsobuje, že si slovenský spisovatel' nevie pomôct' inak, ako charakterizovaním svojich hrdinov zvonka, opisom, a nie zo samotnej ich akcie“ (Mihálik 1947c:418). Ako nebezpečné vnímal „vnútorný rozpor v stavbe diela, dynamickost' výrazu a statickost', strnulost' sujetu“ (Mihálik 1947c: 419). „Hlavná príčina, z ktorej všetky ostatné vyplývajú, je slabá osobná kultúra. Medzi našimi spisovatel'mi je málo takých, o ktorých by bolo možno povedat', že sú osobnostami; nie ani v mravnom zmysle, ale v zmysle utvorenia sa a rastu osobnosti umeleckej; je to predovšetkým vzt'ah zodpovednosti: umelec sa musí stavat' zodpovedne ku všetkým životným faktom, ktoré sa majú stat' podnetom pre vznik diela“ (Mihálik 1947c: 421).

V recenziách sa V. Mihálik prezentoval ako literárne rozhl'adený a suverénny katolícky kritik. Kriticky hodnotil najmä prózu, kde si všímal funkčnost', respektíve nefunkčnost' ornamentu a metafory, čo korešponduje s jeho postojom k Anjelským zemiam. Román P. H. Jurinu Kameň na kameni pozitívne zhodnotil preto, že sa autor podl'a neho dokázal vyhnút manierizmu naturistov. Ocenil jazyk románu, zvlášt' dialóg, ktorý „verne zachytáva mentalitu ludí na kopaniciach a kolorit tohto kraja, tlmočí všeobecný spôsob hovorenia a je svedectvom autorovej intímnej oboznámenosti s prostredím“ (Mihálik 1947b: 635-636). V románe nachádza sociálne a domáce slovenské otázky života na kopaniciach, ale aj problematiku duší zachytenú v najvšeobecnejších polohách, čím román pripomína diela francúzskej katolíckej prózy autorov ako Georges Bernanos a François Mauriac, ktorí líčili „bolestnú stránku krestanstva, kalváriu l'udskej slabosti, katolicizmus, ako sa javí v hriechu, životnú realitu omylov a ustavičného boja s diablom“ (Mihálik 1947b: 635). V Novej práci publikoval V. Mihálik aj niekol'ko recenzií poézie. Zaoberal sa napríklad českou katolíckou poéziou, dielom Jana Zahradníčka a menej známeho Ivana Marianova, ktorých zaradil k línii symbolistickej březinovskej poézie (Mihálik 1947a:311).

Najvýraznejším kritikom a jedným z najagilnejších redaktorov Novej práce bol A. Stankovský12 (občianskym menom Aladár Stankovský, pseudonymy A. S., A. S. Somnambul, A. St., fs, Marta Brezinová, František Slza, Ján Nátoň). V štyridsiatych rokoch bol redaktorom katolíckych časopisov Kultúra a Nová práca. ${ }^{13}$ Novej práci vtlačil pečat' intelektuálneho náboženského periodika, ktoré uverejňuje články s aktuálnou spoločenskou problematikou a v literárnych

12 Do literárneho života vstúpil ako redaktor antológie poézie mladých básnikov Pozdrav mladých, ktorá vyšla v Prešove v roku 1942. Ako básnik debutoval pod pseudonymom František Slza zbierkou Zem bližznych (1947). Pre ranú fázu jeho tvorby (tridsiate a štyridsiate roky 20. storočia) je príznačná silná naviazanost' na dielo R. Dilonga, ktorého obdivoval (Juhásová 2018: 78). J. Motulko v tejto súvislosti písal o Stankovského somnambulskom tvorivom období, v ktorom bol akoby Dilongovým tieňom (Motulko 2002: 10). 13 Po februári 1948 bol z redakcie Spolku svätého Vojtecha odstránený a vyšetrovaný pre kontakty s exulantami, najmä R. Dilongom. Po prepustení z ilavského väzenia pôsobil na východnom Slovensku, hlavne v Humennom, ako osvetový pracovník a kníhkupec. Počas totality mal aj nad'alej problémy so Štátnou bezpečnost'ou, ktorá zhabala jeho rukopisy i listy od Dilonga. Po roku 1989 opät vstúpil do literárneho života. Publikoval poéziu, prózu a recenzie v Slovenských pohladoch, Kultúre, Slovenských národných novinách, Literárnom týźdenníku, Slovenskej republike. Jeho stabilnou témou boli autori katolíckej moderny alebo svetonázorovo blízki autori (R. Dilong, J. Motulko, V. Turčány, S. Veigl, Julo Zborovian). 
502 náboženské knižky, ktoré nemohol ako redaktor časopisu vychádzajúceho pod gesciou Spolku svätého Vojtecha opomenút', predsa sa usiloval dokázat', že spolok nevydáva iba úžitkovú náboženskú literatúru. Recenzoval zahraničnú a slovenskú poéziu a prózu, všímal si knižnú produkciu pražského katolíckeho vydavatel'stva Vyšehrad a iných českých vydavatel'stiev aj knihy vydané v nekatolíckych slovenských vydavatel'stvách (Matica slovenská, Elán, Tranoscius a d'alšie). Bol znalcom a milovníkom francúzskej literatúry, o ktorej je v Novej práci hodne príspevkov. Pri prekladových dielach sa vyjadroval aj k úrovni prekladu.

Recenzie, ktoré A. Stankovský publikoval v Novej práci, sa stabilne začínali informačne hodnotnými kontextovými informáciami o autorovi, literárnej generácii, literárnohistorickými či literárnokritickými hodnoteniami diela. Recenzovanú knihu sa usiloval priblížit čitatel'om tým, že zhrnul informácie o deji, téme či motivickom spektre. Nikdy neostal iba pri povrchovej motivickej štruktúre diela - výstižná a pomerne komplexná, analyzujúca aj syntetizujúca je aj systematická charakteristika poetiky. Bez apriórneho pozitívneho hodnotenia upriamoval pozornost' na biblické alebo náboženské motívy v literárnych dielach, čo sa v recenziách nekatolíckych kritikov vel'mi neobjavovalo. Upozornil napríklad na biblické motívy a mysticizmus Štefana Krčméryho v zbierke Pozdrav odmlčaného básnika, ktorú charakterizoval kultivovaným esejistickým jazykom inšpirovaným výtvarným umením: „Určite je to už staršia škola básnická, ktorú reprezentujú epické ornamenty popri lyrických plastikách a výpravných reliéfoch" (Stankovský 1946e: 57). Nevyhýbal sa kritickým hodnotiacim súdom, a to aj pri renomovaných básnikoch, akým bol Ján Smrek: „Smrekova kniha [zbierka Studňa - poznámka E. P.] má i svoje neduhy: náhodnost', miestami verbálnost', zapáchajúca stuchlinou, čo vel'mi škodí každej studni, no pre tieto nedostatky nemožno zatvorit' oči pred váhou Smrekových básní, ktoré vystihujú čas tak, ako sa nám za posledné roky neraz mihol pred očami“" (Stankovský 1946a: 204).

A. Stankovský sa systematicky venoval hodnoteniu poézie nadrealistov. Aj ked' sám začínal v znamení nadrealistickej poetiky na spôsob R. Dilonga, v tomto období ju už považoval za vyprázdnenú: „nadrealisti sú v kríze, hovoria o nových možnostiach, no prakticky ich vo svojej poézii neprinášajú. Ich poézia nie je čarovným prútikom, ale začarovaným klišé, z ktorého sa tažko prerážajú k naozajstným novotám“ (Stankovský 1946c: 223). Naopak, Vladimírovi Reiselovi vyčítal, že „, explozívnych metaforách prináša tendenčný hrot a prestáva byt' zástancom poézie pure, slúži idei, lepšie povedané ideológii a tým sa väčšmi približuje $\mathrm{k}$ davu, $\mathrm{k}$ mase, čo u našich nadrealistov je problém - problematický “ (Stankovský 1946f: 142). Je možné, že Stankovského názor na nadrealizmus sa zmenil aj pre povojnový príklon nadrealistov k ideológii komunizmu.

Iba príležitostne možno pobadat', že A. Stankovský bol konzervatívnym, nacionálnym typom kritika. Napríklad v článku o Pavlovi Országhovi Hviezdoslavovi explicitne propaguje syntézu hodnôt Boh - národ (Stankovský 1946d:348-349). To sa napokon potvrdilo a ukázalo ako smerodajné aj v jeho neskoršej tvorbe (tiež po novembri 1989, ked' začal znova publikovat'). Ako redaktor časopisu vydávaného Spolkom svätého Vojtecha akceptoval (či toleroval) literatúru s pragmatickým 
náboženským účelom, ktorú sa však snažil minimalizovat'v prospech vydávania 503 krásnej literatúry. Jeho konzervatívna črta akoby bola v konflikte s bohémskym gestom a umeleckou slobodou. Možno to dedukovat' napríklad z recenzie na literárnohistorickú príručku Marcela Horniaka Životné pramene krásneho písomníctva, kde podl'a neho autor ,poukazuje na zhubné účinky takých diel, ktoré po umeleckej stránke môžu byt',krásne', ale nemožno ich odporúčat' alebo prijat' pre ich deštruktívne zámery, pre ich protináboženskú a antimorálnu tendenciu pre ich ciel', ktorým neraz je rozvrátit' v človeku mravný cit a zmysel pre mravnú zodpovednost"“ (Stankovský 1946b: 205).V recenzii na jednej strane schvaluje nejaký typ cenzúry, no v závere relativizuje jej význam v tom zmysle, že cenzúra môže byt' prínosná iba pre tých, ktorí „nie sú schopní sami rozlišovat' a hodnotit', ktorí nie sú schopní sami a samostatne rozmýšlat"“ (Stankovský 1946b:205). Možno usudzovat', že aj vd'aka umelecko-bohémskej črte A. Stankovského cítit' na stránkach Novej práce pochopenie pre slobodu umeleckého slova, čo sa napokon prejavilo akceptovaním takých autorov, akými boli V. Mihálik či M. Válek. Ani jeden z nich netvoril pragmatickú náboženskú tvorbu, obaja boli už vo svojich juveníliách popri využívaní náboženských prvkov aj „,heretickými“ autormi (ako príklad stačí spomenút' Válkovo Ticho nad krajom či Mihálikovu Pesničku si ja hudiem vagabundskú).

\section{Časopis pre krestanskú kultúru Verbum}

Mesačník Verbum s podtitulom Časopis pre krestanskú kultúru vychádzal od novembra 1946 do marca 1948 v náklade tritisíc výtlačkov, čo bolo vzhl'adom na dobové pomery pomerne vysoké číslo. ${ }^{14}$ Jeho redaktori považovali za existenčne dôležité oslovit' a nájst' dostatočný počet čitatel'ov a odberatel'ov. Verbum bolo síce katolícke nakladatel'stvo, no vzniklo z iniciatívy „,zdola“, na podnet kňazov a laikov, ktorých spájala spoločná vízia kultúrnej práce. Finančne nebolo kryté Spolkom svätého Vojtecha ani inou oficiálnou štruktúrou katolíckej cirkvi na Slovensku. Fungovalo na princípe družstva, ktoré finančne dotovali jeho zakladatelia a odberatelia. Knihy z iných vydavatel'stiev získavali výmenou za vlastnú produkciu. Redaktori pracovali zdarma a je nanajvýš pravdepodobné, že ani prispievatelia nedostávali za svoje príspevky honorár (Silan 1998: 117). Podl'a Martina B. Fronca si Verbum t'ažiskovo nepredplácali kňazi, ale najmä laickí inteligenti (lekári, vysokoškolskí učitelia, štátni úradníci, podnikatelia, študenti a podobne). Medzi odberatelmi boli napríklad Laco Novomeský a Gustáv Husák (Fronc 1997: 55). Úvodné číslo časopisu neuvádza nijaký program, no dá sa predpokladat', že práve jeho nezaradenie malo signalizovat' pokračujúcu kultúrnu prácu a nadväznost' na časopis Obroda.

Príznakové je, že redakcia sa prihlásila k idei krestanskej kultúry, nielen katolíckej. Svedčí to o jej snahe prekonávat' mentálne bariéry medzi krestanskými denomináciami na Slovensku a presadzovat' ekumenizmus v oblasti kultúry. Ako uviedol Anton Harčar, jeden z organizátorov nakladatel'stva a časopisu Verbum, názov bol inšpirovaný latinským biblickým citátom vyňatým z Prológu k Evanjeliu svätého Jána ,et Verbum caro factum est“ - ,a Slovo sa telom stalo“ (Ján 1, 14) (Harčar 1997: 42). Redaktori ním akcentovali myšlienkovú blízkost' k teológii vtelenia, ktorá zdôrazňuje záujem Boha o človeka, pozemskú skutočnost',

14 Pre porovnanie, renomovaný literárny a umelecký časopis Elán mal po vojne iba sedemsto predplatitel'ov a zanikol údajne pre nedostatok financií (Drug 1999: 131). 
504 súčasnost', dejiny vôbec, čo má byt' smerodajné aj pre krestanské chápanie viery $\mathrm{v}$ Boha - transcendentného a imanentného zároveň. ${ }^{15} \mathrm{Z}$ celého biblického verša ostalo v názve časopisu iba klúčové slovo - verbum, ako výstižný titul pre periodikum zaoberajúce sa krestanskou kultúrou, pretože slovo je významným prameňom viery a zároveň aj prejavom kultúry. ${ }^{\mathbf{1 6}}$

Ideovými vodcami Verbumu boli Ladislav Hanus a J. Kútnik Šmálov. Nefigurovali však v oficiálnych štruktúrach časopisu ani vydavatel'stva (Hanus 1992: 94). Toto riešenie považovali za vhodnejšie, netajili sa totiž súhlasným stanoviskom k slovenskej autonómii a razantne odmietavým postojom ku komunizmu. L. Hanus podpisoval svoje články v časopise vlastným menom, J. Kútnik Šmálov používal viacero pseudonymov (Matúš Zjara, K. Kamenský, Actor), možno aj preto, že sám bol polemického naturelu a viac sa púštal do spoločenských polemík. K takémuto kroku ho zrejme viedla opatrnost' v nestabilnej politickej situácii, ked'že v roku 1945 bol väznený a odsúdený do pracovného tábora. ${ }^{17}$

Obaja redaktori aj tretí člen redakčného kruhu, Belo Fronc, vtlačili vydavatel'stvu a časopisu pečat', ktorá zodpovedala ich víziám o d'alšom smerovaní katolíckej cirkvi na Slovensku. Ďalšími členmi redakčnej rady boli Vendelín Jankovič, Jozef Bánsky, Ján Švec Slavkovian a J. Silan (Balúnová - Mihóková - Lukáč 1995: 876). Zakladatelia dokázali sústredit' okolo Verbumu schopných mladých i skúsenejších redaktorov a prispievatel'ov. Okrem Košíc a Spiša boli početnejšie zastúpení bratislavskí spolupracovníci, ktorí pochádzali z okruhu známych J. Kútnika Šmálova z čias jeho štúdia na Filozofickej fakulte Slovenskej univerzity.

J. Felix nazval autorov združených okolo Verbumu verbumistami a vnímal ich ako skupinu s vyhranenou literárnou aktivitou (Felix 1991: 80). Časopis mal primárne oslovit' čitatel'ov z radov krestanskej inteligencie, aby boli vzdelaní nielen vo svojej profesii, ale aj v otázkach viery a kultúry. Zámerom však bolo vychádzat' tiež za hranice cirkevného prostredia a oslovit' všetkých, ktorí mali záujem o kultúru a umenie. Redaktorom šlo o umeleckú, nie úžitkovú náboženskú literatúru, čím sa katolícka kritika Verbumu podstatne odlišila od Novejpráce. Priorita spočívajúca v odmietaní účelovosti v náboženskej produkcii a nástojčivo volajúca po umeleckej hodnote korešponduje s kritikou slovenského katolicizmu, ktorú priniesol L. Hanus v knihe Rozprava o kultúrnosti (Hanus 1943).

Počas krátkej existencie časopisu vyšlo osemnást' čísel, ktoré dostatočne potvrdzujú koncepčnost' práce redaktorov a okruhu prispievatel'ov. Možno súhlasit'

15 Základné myšlienky teológie vtelenia vysvetluje článok Ladislava Hanusa Krestan a dejiny. V ňom sa takisto argumentačne opiera o citát ,,et Verbum caro factum est“: „ZZ Vtelenia [Cirkev-pozn. E. P.] vyvodzuje jedine správny špeciálny krestanský princíp náhladu a konania v histórii. Slovo telom sa stalo a prebývalo medzi nami. Hlavným poslaním krestanstva je vtel'ovat'Boha do ludských poriadkov" (Hanus 1947: 211). 16 Časopis sa „,v duchu pápežských sociálnych encyklík a na princípoch katolíckej viery snažil prispiet’ k ozdraveniu spoločenských pomerov. Bol mu vonkoncom cudzí nielen liberalistický kapitalizmus, ale aj každý taký sociálny systém, ktorý narušuje dôstojnost' a hodnotu človeka. Preto sa zo všetkých síl pričiňoval o udomácnenie zásad katolíckeho integrálneho humanizmu a personalizmu u nás a o ich dôslednú aplikáciu v sociálnej sfére. A aj v tomto ukazoval na ozdravujúce sily katolíckeho náboženstva myšlienky a skutku, dnes a od začiatku v rozvrátených povojnových časoch“ (Harčar 1997: 42).

17 V Archíve Ústavu pamäti národa sú evidované informácie o J. Kútnikovi Šmálovovi vo zväzku so signatúrou KS ZNB S ŠtB Bratislava, BA-S, arch. č. 102. Ďalšie informácie týkajúce sa jeho odsúdenia sú v nasledujúcich fondoch: Tábor nútených prác Hronec E 91, arch. č. 10, Tábor nútených prác Nováky E 98, arch. č. 17, Tábor nútených prác Ilava E 97, arch. č. 12, 14. 
s Petrou Bombíkovou, ktorá zhrnula priority časopisu do troch oblastí:1. integrálny 505 (krestanský) humanizmus, ktorý sa chápal ako teologická a filozofická generačná platforma; princíp integralizmu sa nachádzal už vo filozofii svätého Tomáša Akvinského; z európskych dobových myslitel'ov ho najväčšmi reprezentoval Jacques Maritain, ktorého interpretovali L. Hanus, Štefan Hatala a d'alší prispievatelia Verbumu; 2. koncepcia umenia a literatúry, ktorá nadväzovala na filozofickú koncepciu integralizmu; teoreticky ju rozvíjal najmä J. Kútnik Šmálov; vyjadroval sa o potrebe svetonáhl'adu pri poznávaní a hodnotení umenia; názorovo sa priblížil koncepcii J. Felixa; 3. diskusie o vzt́ahu krestanstva k socializmu a o aktuálnych spoločenských zmenách, ku ktorým sa autori príspevkov snažili zaujat' jednoznačné stanovisko podložené hlbšími analýzami (Bombíková 1998: 199-201).

Redaktori Verbumu ignorovali prípisy Povereníctva informácií, ktorými bol vyvíjaný tlak na redaktorov novín a časopisov, aby nekritizovali štátne inštitúcie ${ }^{18}$ či neironizovali ,zaslúžilé osobnosti“, čo sa ad hoc považovalo za fašisticko-nacistickú praktiku. ${ }^{19}$ Naopak, od prvého čísla až po posledné redakcia jednoznačne odmietala politizáciu kultúry, jej prejavy a dôsledky. Spoločenskej kritike sa venovala špeciálna rubrika Nákova, v ktorej sa otvorene pertraktovali otázky politizácie kultúry a literatúry na Slovensku, presadzovania jedinejideológie aj s poukázaním na krízovú situáciu umelcov v Sovietskom zväze (reštrikcie proti sovietskym spisovatel'om Michailovi Zoščenkovi a Anne Achmatovovej), šírenia atmosféry strachu v spoločnosti znemožňujúce verejnú diskusiu a podobne. To všetko boli spoločensky pálčivé témy.

Paradoxné je, že vydávanie časopisu bolo zastavené 20. marca 1948, dva dni po verejnom vyhlásení štátnych predstavitel'ov o náboženskej slobode v krajine. Nariadenie sa realizovalo s okamžitou platnost'ou (Drug 1993: 85). Po tom, čo sa redaktori prihlásili k pôvodnej koncepcii krestanskej kultúry a vyjadrili lojalitu s biskupmi, bolo o osude periodika definitívne rozhodnuté. Posledné publikované číslo Verbumu neobsahuje žiaden epilóg ani neuvádza, že vydávanie časopisu je pozastavené, hoci redakčný kruh už o tejto skutočnosti vedel. Detaily a okolnosti, ktoré by širšie osvetlili fungovanie časopisu, a to nielen v posledných dňoch jeho existencie, nepoznáme, lebo jeho archív (na rozdiel od archívu Novej práce) sa nezachoval. Reštrikcie sa zatial' ešte nedotkli činnosti vydavatel'stva Verbum, takže práca na knižných edíciách pokračovala d'alej. Napríklad na jeseň 1948 bola vydaná Silanova posledná predtotalitná, spoločensko-kritická zbierka Úbohá duša na zemi, azda jediná kniha spoločenského odporu, ktorá vyšla ešte v aktuálnom čase svojho vzniku.

\section{Profilácia literárnych príspevkov a literárna kritika v časopise Verbum}

Časopis uverejňoval literárnovedné štúdie, kratšie články, poznámky, referáty. Glosy sa zameriavali na aktuálne umelecké dianie na Slovensku a vo svete. Rubrika Domov prinášala erudované články z dejín slovenskej literatúry a kultúry. Ich autori sa vyslovovali k témam, ktoré sa týkali duchovných základov slovenskej

18 Spolok svätého Vojtecha v Trnave, Archív SSV, fond Nová práca: Povereníctvo informácií. Signatúra Scr XIII č. 1/554, 11. marec 1947.

19 Spolok svätého Vojtecha v Trnave, Archív SSV, fond Nová práca: Povereníctvo informácií. Signatúra Scr XIII č 1/556c, 14. apríl 1947. 
506 kultúrnosti (Vel'ká Morava, kamaldulská Biblia), osobností a klasikov slovenskej kultúry (autori romantickej generácie, Š. Moyzes, P. O. Hviezdoslav), ale aj tém pozornosti katolíckych autorov zo zahraničia, ktorí neboli slovenským čitatel'om dostatočne známi (Hana Malewska, Jerzy Zawieyski, Felix Timmermans). Cenné sú monotematické čísla prinášajúce celistvejší literárny portrét vybraného autora (P. Claudel, Franz Werfel, Max Jacob). Podl'a Michala Fedora Verbum „programovo spájal slovenskú kultúru so svetovou kultúrou“ (Fedor 1992: 47).

Verbumisti, na rozdiel od Novej práce, odmietali venovat pozornost' literatúre poznačenej náboženským pragmatizmom. Ich ambíciou bolo vstúpit na pôdu národnej, nie cirkevnej kultúry. Hoci oba časopisy vznikli na identickej náboženskej platforme, boli voči sebe kritické. Kým obojstrannú morálnu podporu možno identifikovat' z faktu vzájomného recenzovania vydaných kníh, kritický vztah voči „,bratskému“ časopisu sa dá vyčítat' z viacerých článkov. ${ }^{20}$ Možno aj pre takéto kritické poznámky napísal A. Stankovský J. Silanovi v liste z roku 1947, že má voči Verbumu „niektoré výhrady menšieho významu“,21 a aj s odstupom desatročí vyhlásil: „Verbum ani Obroda mi neprirástli k srdcu, pretože vytvorili okolo seba dost' chladné prostredie akejsi duchovnej aristokracie“" (Stankovský 1997: 97).

Jednou z prioritných literárnych tém prispievatel'ov časopisu Verbum, v ktorej sa mimochodom zhodli s Novou prácou, bola otázka realizmu v slovenskej a vo svetovej literatúre. Pozornost' katolíckych literárnych kritikov pútal najmä Fiodor Michajlovič Dostojevskij. Jozef Bánsky, Ignác Gašparec a Marián Temeš nadviazali na sériu článkov L. Hanusa, ktorý sa Dostojevským zaoberal na začiatku štyridsiatych rokov. Z iných autorov to boli napríklad Ivan Alexandrovič Gončarov, Ivan Sergejevič Turgenev či Romain Rolland.

V časopise vyšla programová stat' Jerzyho Zawieyského o integrálnom katolíckom realizme v literatúre, v ktorej autor formuloval názor, že hlavnou zásadou katolíckeho spisovatel'a by malo byt' nefalšovat' život, čo znamenalo, že katolícky spisovatel' má vo svojom diele zobrazit úplnost' života, tak úpadok, ako aj vzrast. J. Zawieyski požadoval od katolíckej literatúry umeleckú hodnotu. Podla neho nemôže byt' pre katolícku literatúru príznačná devótna téma, ale „sensus catholicus“, pričom tento pojem prevzatý zo slovníka tomistov charakterizoval ako „prúd vnútorného diela, jeho atmosféru, lebo nebo jasne sa odzrkadluje v kalužiach a blate života“" (Zawieyski 1947: 520). Hlavnou záležitostou, o ktorú sa opiera sensus catholicus literárneho diela, je otázka vztahu človeka k Bohu a životu (Zawieyski 1947: 523). Koncepcia integrálneho krestanského realizmu nemala byt' identická s tradíciou umeleckého realizmu, ktorý bol pesimistický,

20 Napríklad voči literárnemu súbehu, ktorý vyhlásil Spolok svätého Vojtecha a vyhradil naň značnú sumu, 650000 korún, sa ohradil J. Kútnik Šmálov (pod pseudonymom Actor) a spochybnil desat'z trinástich sútažných kategórií, v ktorých mali byt' odmenené iba „podielové knihy“, prípadne „texty cirkevných otcov" (Kútnik Šmálov 1947f: 543-544).

21 Literárny archív Slovenskej národnej knižnice Martin, osobný fond Janko Silan: List Aloša Stankovského Jankovi Silanovi. Signatúra 210 K 2, 1947. 
bezvýchodiskový a podliehal schéme, podla ktorej „len zlo a úpadok možno zvý- 507 raznit' prostriedkami umenia" (Zawieyski 1947: 523).

Literárny program integrálneho krest'anského realizmu vychádzal z filozofie svätého Tomáša Akvinského, ktorú v dobovom kontexte aktualizovali novotomisti. V časopise Verbum ho filozoficky presadzoval Ferko Skyčák. J. Kútnik Šmálov sa ho snažil adaptovat' aj ako estetickú platformu. Literárnoteoreticky sa opieral o koncept Giovanniho Papiniho (1881 - 1956), ktorého Essaye o umení preložil Mikuláš Šprinc. ${ }^{22}$ Taliansky žurnalista, konvertita ku katolicizmu G. Papini kritizoval koncept čistej poézie a jej básnikov nazval dezinfikátormi (Papini 2008: 270). Podl'a neho literatúra ,vyžaduje celé bytie, všetky potencie ducha (a v istom zmysle aj tela). [...] Všetko chýba v poézii, ak chýba čo len jedna vec“ (Papini 2008: 271-272). Inými slovami vlastne sformuloval to, čo J. Kútnik Šmálov kritizoval na katolíckych modernistoch surrealistického štýlu, na R. Dilongovi a P. Gašparovičovi Hlbinovi. Integrálny krestanský realizmus, ako ho J. Kútnik Šmálov chápal, adaptoval z personalizmu, novotomizmu a teológie vtelenia a tiež z už uvedených zahraničných literárnych konceptov (Zawieyski, Papini). Dotýkal sa nielen témy, štýlu, ale aj autorského zážitku, ktorý mal byt' komplexný, zahŕňajúci intelekt i zmyslovost'.

Redakcia Verbumu sa usilovala zadefinovat', teoreticky koncepčne podchytit' a formovat' literárny kánon modernej katolíckej literatúry, a zároveň podnietit' autorov k tomu, aby ho prakticky realizovali a naplnili. Podobne ako u J. Felixa a socialistických realistov, aj v katolíckej literárnej komunite vzrastala požiadavka po návrate realizmu, v tomto prípade špecificky katolíckeho, integrálneho realizmu, v ktorom by čitatel' mohol identifikovat' sensus catholicus. J. Kútnik Šmálov v povojnovom období prehováral svojho oblúbeného básnika V. Beniaka, aby napísal román, ktorý - ako dúfal - by mal kvality katolíckeho realistického románu:

„Práve preto, že si tak sám, tak utiahnutý, nový druh práce bude pre teba vykúpením. Máš bohaté tvorivé skúsenosti a hlboké fondy. Tvoj umelecký vkus Ta povedie týmto strašne širokým terénom bezpečne. A bude to naozaj zaujímavé, kam a ako. Viem si predstavit', ako Ťa to chytí. Len pre Boha, nič časového, nič tendenčného, tak jasne ludsky, tak pravdivo a úprimne, tak vidiaco o tom, čo je v človeku ludského a v živote zázračného. Človek musí čosi mat', aby mohol písat'. Potom je všetko ostatné vedlajšie. Akosi samočinne sa vynorí. Ale škoda reči. To sú pre Teba dôverne blízke veci. Nože, do toho!“23

Z citovaného textu je zjavné, že katolícky realistický román mal mat' opačné kvality ako socialisticko-realistický román („nič časového, nič tendenčného“). Vo svojom naliehaní na V. Beniaka neustával J. Kútnik Šmálov ani v roku 1949, ked' ho povzbudzoval k napísaniu iného nonfiktívneho, realistického žánru: „zišli by sa najmä state, čosi ako memoáre. Autobiografia bola by napokon pre Teba oddychom. Rozumiem autobiografiu skutočnú, tak pre seba, bez ohladu

22 Kniha bola úspešná, v slovenskom preklade bola vydaná v roku 1943 a už v roku 1945 sa dočkala druhého vydania.

23 Slovenská národná knižnica v Martine, Literárny archív (LA SNK), osobný fond Valentína Beniaka: List Jozefa Kútnika Šmálova Valentínovi Beniakovi. Signatúra 131 C 40, 21. júl 1946. 
508 na publikum: pohl'ad dozadu, účtovanie, zvažovanie skúseností. Takými autobiografiami národ rastie." 24

Redaktori a prispievatelia Verbumu sa zaoberali tiež kritikou kritiky. Aj v tomto smere možno vidiet' snahu prispievatel'ov o profesionálnost'a nepredpojatost'. Výrečnými môžu byt' dve reakcie na monografiu Alexandra Matušku o Svetozárovi Hurbanovi Vajanskom, raz formou glosy v časti Domov a raz ako recenzný príspevok v rubrike Knihy. Ani jeden z autorov nebral do úvahy opozitné politické názory A. Matušku a nestaval sa preto voči jeho knihe odmietavo.

Glosátor s autorskou značkou X vyčítal A. Matuškovi, že S. H. Vajanského „berie ako súčasníka a odsudzuje jeho umelecký postup nie z hl'adiska dobového zaradenia, ale z dnešného hl'adiska“ (X 1947:329). Poukazoval na nezohl'adnenie historickej poetiky a sociológie kultúry. Následne sa pokúsil o vysvetlenie dobovej spoločenskej situácie. Podl'a neho si celá martinská generácia osvojila porazeneckú taktiku a „nepochopila kardinálnu prestavbu európskej spoločnosti“ (X 1947: 330). Takéto chápanie európskej spoločnosti i slovenského národa (povýšenectvo voči „,skazenému Západu“, nezáujem o robotníkov, pridržiavanie sa zemianstva) autor príspevku odsudzuje, čím sa približuje k Matuškovmu kritickému nazeraniu, aj ked' vyjadruje názor, že A. Matuška súdil prozaické dielo S. H. Vajanského neadekvátnymi prostriedkami (X 1947: 329-330).

Druhý text reagujúci na A. Matušku, recenziu jeho literárnohistorickej monografie, napísal J. Kútnik Šmálov, zakrytý pseudonymom M. Zjara. Na štýle recenzie vidno, že kritik sympatizuje s Matuškovým ostrým, demýtizujúcim štýlom, súhlasí s ním a chváli ho. Matuškov kritický štýl, rúcajúci v slovenskom národnom živote modly, očividne konvenoval polemickému naturelu J. Kútnika Šmálova. Podl'a neho Matuška „nebojuje len s Vajanským. Bojuje viac s tými, čo ho mumifikovali a čo jeho múmiu vytrvalo udržiavajú medzi živými“ (Kútnik Šmálov 1947h:366), teda s tendenciou vytvárat' okolo spisovatel'ov auru legendy. V závere recenzie vyzýva A. Matušku ku kritickému postoju voči súčasnej literatúre, doslova ho provokuje, nech „tú istú odvahu, akou dobijal mŕtveho, prejaví aj k živým, “ pretože „tabu za nami nie je vlastne až tak nebezpečné ako tabu v nás a okolo nás“ (Kútnik Šmálov 1947h: 367).

J. Kútnik Šmálov bol najvýraznejšou kritickou osobnostou z redaktorov a prispievatel'ov Verbumu. Vystupoval ako tradicionalistický kritik, zaoberal sa slovenskou kultúrnou tradíciou, ktorú sa usiloval reflektovat', aktualizovat' a usmerňovat'. Toto zacielenie vymedzilo okruh autorov a diel, na ktoré zameral svoju pozornost': prevažne vel'kí autori-klasici (napríklad P. O. Hviezdoslav a S. H. Vajanský) a vel'ké diela slovenskej literatúry (napríklad Sládkovičova Marína). Podnecoval novú konkretizáciu klasického kánonu diel slovenskej literatúry, aby sa tradícia nestala frázou. Pri príležitosti dvadsiateho piateho výročia smrti P. O. Hviezdoslava konštatoval, že na Slovensku vládne l'ahostajnost' voči jeho dielu, čo považoval za nevyužitý kultúrny kapitál (Kútnik Šmálov 1946b: 35). Skutočnost', že tým nemyslel pochvalné slávnostné reči, dosvedčuje fakt, že pochválil Jána E. Bora, ktorý sa, najmä pre verbalizmus, vyslovil kriticky k Hviezdoslavovmu dielu. J. Kútnik Šmálov kritizoval formalizmus ako metódu interpretácie diela tohto

24 LA SNK, osobný fond Valentína Beniaka: List Jozefa Kútnika Šmálova Valentínovi Beniakovi. Signatúra 131 C 40, 21. máj 1949. 
básnického velikána, pretože nereflektoval na ideové a etické zložky, hoci zjavne 509 išlo o diskurzívneho autora (Kútnik Šmálov 1946b:36-37). Aj pri S. H. Vajanskom žiadal ,jeho zaradenie do živej národnej tradície, ktorá si z minulosti vyberá momenty príhodné na prítomnostné utuženie“, pretože „národná tradícia je dynamický faktor s neustálymi preskupovaniami““ (Kútnik Šmálov 1947a: 233). Usiloval sa doplnit' tradíciu o katolíckych vzdelancov nedocenených literárnou históriou (Jozef Kohút, Jozef Karol Viktorin) a kritiku smeroval do vlastných radov, k nezáujmu o vlastné kultúrne dejiny u katolíkov (Kútnik Šmálov 1948e:348-349).

Na stránkach Verbumu sa J. Kútnik Šmálov prezentoval aj ako prísny strážca demokracie, zdôrazňoval potrebu rôznorodosti v kultúre a pluralizmus tradície. Pri rôznych príležitostiach sa kriticky vyjadroval k procesu politizácie kultúry, straníckej zaujatosti, ku skupinárskym záujmom, ku ktorým dochádzalo v povojnovej kultúre. L'ud'om zodpovedným za kultúrny život vyčítal úzky, spolitizovaný výber delegácie na zasadnutie UNESCO. Kritizoval vytváranie nepriatel'ského obrazu o cirkvi a krestanstve v spoločnosti na základe poloprávd i vyslovených lží politikov (Kútnik Šmálov 1947c: 150; Kútnik Šmálov 1947g: 190-191). Poukazoval na pol'skú literatúru, kde prebiehala plodná diskusia marxistických a krestanských kritikov a autorov (Kútnik Šmálov 1947d:161). Volanie po demokracii a odmietanie autoritatívnych metód v kultúre zaznieva aj v jeho kritike rozhodnutia Umeleckej a vedeckej rady o knihách, ktoré mali byt' preložené do svetových jazykov, kde už absentovali mená ako V. Beniak, M. Urban, J. C. Hronský (Kútnik Šmálov 1947b: 254-255). Opätovne vyjadroval potrebu otvorenej diskusie, z ktorej vzíde súd o hodnote alebo nehodnote diela, pretože ,nemôžu hrat' iba jedny husle, a k tomu iba s jednou strunou“ (Kútnik Šmálov 1946a: 96). Odmietal kolektivizmus ako slepú uličku a staval sa na stranu humanizmu (Kútnik Šmálov 1947d: 160).

Pre literárnokritickú metódu J. Kútnika Šmálova je príznačné, že popri samotnom diele sa zaoberal aj osobnostou básnika a jeho básnickou skúsenostou. Bol totiž presvedčený, že aj osobnost' je kultúrnym faktom (Kútnik Šmálov 1948d: 334). Išlo mu pritom viac o fenomenologicky poňatú skúsenost', nie o konkrétne žité fakty, ako to vidiet' napríklad v rozsiahlej recenzii Poézia životného kladu, kde hodnotil diela autorov katolíckej moderny. Vychádzal v nej z predpokladu, s ktorým prišiel už Henri Brémond, že v lyrike najpodstatnejšie ,je vlastne to nezmeratel'né a slovami nezachytitel'né, čo sa len chveje a vzlyká a plesá v rytme nedohovoreného, lebo nevysvetlitel'ného" (Kútnik Šmálov 1947e: 56). Následne vyjadruje dialektický vztah, ktorý panuje medzi skúsenost'ou a lyrikou:

„Poézia [...], lyrika kryštalizuje básnickú skúsenost', videnie, poznanie a dáva im pevný tvar. [...] Ak poézia nepresahuje slová a obrazy, do ktorých sa ukladá, ale ktoré sú iba penou na vlne oživujúceho, hoci neviditel'ného spodného prúdu, stáva sa neodvratne literatúrou, ktorej je vždy mnoho, kým poézie je vždy málo. [...] Každý z nich [t. j. J. Silan, J. Motulko, J. Haranta - pozn. E. P.] zaujíma vo vývine slovenskej poézie osobitné postavenie, lebo predstavuje osobitné tendencie. Spoločné im je úsilie nájst' rovnováhu medzi tvarom a stvárňovanou skúsenostou, zážitkom. Tvar im je nie cielom, ale iba umeleckou projekciou vnútra cez slovo. Touto stránkou sú silným protikladom preexponovaného estetizmu“ (Kútnik Šmálov 1947e: 56-59). 

ný tvar, ale zároveň aj spôsob, akým zaobchádza so svojou básnickou či s ludskou skúsenostou.

J. Kútnik Šmálov sa dištancoval od romantizmu, ktorý „odkryl svoje filozofické omyly“ (Kútnik Šmálov 1947d: 159), ale aj od neoromantizmu, ako nazýval avantgardu. Pri tejto téme zvažoval takisto otázku, ako „rozšírit' hranice umenia, aby neslúžilo iba elite“ (Kútnik Šmálov 1947d: 159) a zároveň aby sa neprispôsobovalo vkusu publika. Opakovane vyhlasoval, že „katolícki teoretici [...] sa stavajú kladne k heslu realizmu (pravdivá krása) a k etickej zodpovednosti literatúry. [...] Pritom sa stavajú proti mýtu o didaktizme realizmu. [...] Prijímajú humanistický postoj. [...] Z čisto literárnovedného hl'adiska odmietajú činnú, eliminačnú metódu, nehumanistický postoj inkvizítora spoločenského realizmu“ (Kútnik Šmálov 1947d: 160). Realizmus podla neho vyrovnáva dve krajné stanoviská, a to umenie pre umenie a umenie pre život.

Tento kritik aj celá redakcia Verbumu sa zasadzovali za odstránenie konfesionalizmu v umení. Zhodli sa v tvrdení, že konfesionalizmus je chorý prejav v slovenskej kultúre a je potrebné odstraňovat' ho. ${ }^{25} \mathrm{~J}$. Kútnik Šmálov viackrát tematizoval prienikové témy, ktorými búral tabu a klišé, napríklad v článkoch Celibát a slovenský národný život (Kútnik Šmálov 1948a), K problému konverzií a katolizujúcich alebo luteranizujúcich tendencií (kde vyzýval k napísaniu dejín duše napríklad M. Kukučína či A. Sládkoviča; Kútnik Šmálov 1948c), J. M. Hurban a dogma o pápežskej neomylnosti (s tvrdením, že J. M. Hurban nepoznal katolícku náuku o pápežskej neomylnosti, iba mystifikoval; Kútnik Šmálov 1948b). Napokon, posledné dvojčíslo Verbumu, ktoré vyšlo v marci 1948, sa venovalo téme luteranizmu s ciel'om odstránit' negatívne „citové uzly“ (Vstupné slovo 1948:370), a to trpezlivou a úprimnou snahou po obojstrannom poznaní a porozumení.

Ako redaktor Verbumu využil J. Kútnik Šmálov skúsenosti, ktoré získal pri redigovaní časopisu Obroda. K spolupráci dokázal nadchnút viacero svojich známych, ktorých spoznal počas štúdia v Bratislave. Autorsky bol jedným z najstabilnejších prispievatel'ov. Vstúpil do všetkých zásadných tém, ktoré časopis nastolil. Jeho články prezrádzajú mimoriadnu literárnohistorickú a literárnokritickú erudíciu. Svoj polemický charakter využil v zasadení sa za hodnoty v slovenskej literatúre a na obranu demokracie v povojnovej spoločnosti. Bol schopný vízie v smerovaní slovenskej kultúry, ktorú dokázal realizovat' drobnými, ale vytrvalými krokmi. Určite aj vd’aka rozsiahlej činnosti J. Kútnika Šmálova platia slová A. Mráza, že katolícki spisovatelia okolo časopisu Verbum tvoria zoskupenie s výrazným kultúrnym programom.

\section{Záver}

Kontextová historická charakteristika časopisov Nová práca a Verbum ukázala ich spoločné aj odlišné znaky. Hoci boli obe periodiká katolícke, ich programy nepredstavovali zdvojenie, ale v oblasti kultúrnej práce sa vzájomne dopínali.

Nová práca bola výrazom oficiálnej štruktúry katolíckej cirkvi pri Spolku svätého Vojtecha v Trnave. Spolok finančne kryl náklady na tvorbu časopisu

25 Verbum mal v nadpise charakteristiku revue pre krestáanskú, nie pre katolícku kultúru, čím jeho redaktori chceli podporit' ekumenizmus v kultúrnych snahách oboch konfesií. 
a usmerňoval literárne príspevky. Napriek tomu redakcia dokázala prekročit' tieto faktické obmedzenia a prinášala cenné literárne a literárnokritické články. Z redakčného kruhu sa literárnym témam venoval A. Stankovský. Svojou literárnokritickou činnostou sa usiloval prekonat' pragmatické zameranie spolkových kníh. Pozitívom bola aj jeho cielená spolupráca so zahraničnými katolíckymi spolkami (najmä s francúzskymi) a so zahraničnými katolíckymi spisovatel'mi. V časopise poskytoval priestor mladým talentovaným básnikom a kritikom, napríklad V. Mihálikovi. Z jeho literárnych príspevkov je najdôležitejšia polemika o anjelské zeme a vystúpenie za literárny realizmus.

Časopis Verbum vznikol ako prejav iniciatívy ,zdola“, na podnet konkrétnych kňazov a laikov, bez podpory cirkevnej inštitúcie, ako súčast' vydavatel'stva s identickým názvom. Presadzoval vlastný kultúrny program, jeho súčastou bolo napríklad zasadzovanie sa za integrálny katolícky realizmus, ktorý by bol schopný konkurencie voči ,ateistickému“ literárnemu realizmu. Prostredníctvom rubriky Nákova plnil aj spoločensko-kritickú funkciu. Redaktori Verbumu boli v porovnaní s Novou prácou ovel'a odvážnejší v šírení krestanskej kultúry. Jedným z najagilnejších redaktorov bol J. Kútnik Šmálov, ktorý svoj polemický naturel využil na kultúrny boj s nastupujúcou totalitou. Okrem toho sa zasadzoval za oživenie a zvnútornenie posolstva klasikov slovenskej kultúry, otváral otázky konfesionalizmu, pričom bol presvedčený, že ho treba prekonávat', a to najmä v kultúre a umení. Orientoval sa tiež na búranie povrchných klišé a tabuizovaných tém. Spomedzi katolíckych kritikov aktívnych v rokoch 1945-1948 na stránkach Novej práce a Verbumu predstavuje najvýraznejšiu osobnost', ktorá svojou literárnohistorickou a literárnokritickou erudíciou d'aleko presiahla úroveň ostatných recenzentov.

\section{Archívne pramene}

Slovenská národná knižnica v Martine, Literárny archív, osobné fondy Janko Silan, Valentín Beniak.

Spolok svätého Vojtecha v Trnave, Archív SSV, fond Nová práca.

Archív Ústavu pamäti národa v Bratislave, zložka Jozef Kútnik Šmálov, fondy KS ZNB S ŠtB Bratislava; Tábor nútených prác Hronec; Tábor nútených prác Nováky; Tábor nútených prác Ilava.

\section{Pramene}

A. P., 1946. Doprava či dolava? Nová práca, roč. 2, č. 3-4, s. 61.

BUTVIN, Jozef [fn], 1946. Henry Bourdeauw: Roquevillardovci. Nová práca, roč. 2, č. 4, s. 56-57. FELIX, Jozef, 1946. O nové cesty v próze. Problém anjelských zemí v našej literatúre. Elán, roč. 16 , č. 3-4, s. 6-7.

FELIX, Jozef, 1991. Prehl'ad slovenskej literárnej tvorby v roku 1947. In FELIX, Jozef. Literárne križovatky I. Bratislava: Slovenský spisovatel'. ISBN 80-220-0163-5.

HANUS, Ladislav, 1947. Krestan a dejiny. Verbum, roč. 1, č. 5, s. 207-217.

HERISSAY, Jacques, 1947. Dva katolícke romány. Nová práca, roč. 3, č. 4, s. 244-245.

KÚTNIK ŠMÁLOV, Jozef [ACTOR], 1947b. Hlas tak trochu skeptický. Verbum, roč. 1, č. 5, s. 254-255.

KÚTNIK ŠMÁLOV, Jozef [ACTOR], 1947c. Legendárne a pôvodné krestanstvo. Verbum, roč. 1 , č. 3-4, s. 150-152.

KÚTNIKŠMÁLOV, Jozef [ACTOR], 1947f. Slovo k súbehu SSV. Verbum, roč. 1, č. 10, s. 543-544. 
KÚTNIK ŠMÁLOV, Jozef [ACTOR], 1948c. K problému konverzií a katolizujúcich alebo luteranizujúcich tendencií. Verbum, roč. 2, č. 7-8, s. 447-448.

KÚTNIK ŠMÁLOV, Jozef [KAMENSKÝ, K.], 1946a. Husle s jednou strunou? Verbum, roč. 1 , č. 2, s. 95-96.

KÚTNIK ŠMÁLOV, Jozef [KAMENSKÝ, Kliment], 1947g. Tma o stredoveku, nie v stredoveku. Verbum, roč. 1, č. 3-4, s. 190-191.

KÚTNIK ŠMÁLOV, Jozef [M.Z.], 1947a. Boj o Vajanského trvá. Verbum, roč. 1, č. 5, s. 231-233. KÚTNIK ŠMÁLOV, Jozef [M. Z.], 1948a. Celibát a slovenský národný život. Verbum roč. 2, č. 7-8, s. 448-449.

KÚTNIK ŠMÁLOV, Jozef [M. Z.], 1948e. 120 rokov od narodenia Jozefa Kohúta. Verbum, roč. 2, č. 6, s. 348-349.

KÚTNIK ŠMÁLOV, Jozef [ZJARA, M.], 1948b. J. M. Hurban a dogma o pápežskej neomylnosti. Verbum, roč. 2, č. 7-8, s. 440-446.

KÚTNIK ŠMÁLOV, Jozef [ZJARA, Matúš], 1946b. Hviezdoslav stále živý. Verbum, roč. 1, č. 1, s. 34-38.

KÚTNIK ŠMÁLOV, Jozef [ZJARA, Matúš], 1947d. Odklon od romantizmu a príklon k realizmu v pol'skej literatúre. Verbum, roč. 1, č. 3-4, s. 154-161.

KÚTNIK ŠMÁLOV, Jozef [ZJARA, Matúš], 1947e. Poézia životného kladu. Verbum, roč. 1, č. 1, s. 56-59.

KÚTNIK ŠMÁLOV, Jozef [ZJARA, Matúš], 1947h. Vajanský prozaik. Verbum, roč. 1, č. 6-7, s. 366-367.

KÚTNIK ŠMÁLOV, Jozef [ZJARA, Matúš], 1948d. Stelesnenie slovenského génia. Za Jozefom Škultétym, bat'kom a patriarchom. Verbum, roč. 2, č. 6, s. 334-338.

MIHÁLIK, Vojtech, 1946. Pesničku si ja hudiem. Nová práca, roč. 2, č. 15-16, s. 245.

MIHÁLIK, Vojtech [VM], 1947a. Jan Zahradníček: Svatý Václav. Nová práca, roč. 3, č. 5, s. 311-312.

MIHÁLIK, Vojtech [VM], 1947b. Pavol Hrtus Jurina: Kameň na kameni. Nová práca, roč. 3, č. 10, s. 635-636.

MIHÁLIK, Vojtech, 1947c. Súčasná slovenská próza v zrkadle kritiky. Nová práca, roč. 3, č. 7-8, s. 412-422.

MLÁDEŽ debatuje, 1948. Nová práca, roč. 4, č. 2, s. 116-117.

NÁDEJE katolíckej poézie, 1947. Nová práca, roč. 3, č. 6, s. 336-340.

PAPINI, Giovanni, 2008. Úprimne o poézii. In Poézia slovenskej katolíckej moderny. Výber zostavil a doslov napísal Milan Hamada. Bratislava: Kalligram - Ústav slovenskej literatúry SAV, s. 269-272. ISBN 978-80-8101-125-2.

REDAKCIA, 1948. Ako doteraz. Nová práca, roč. 4, č. 1, s. 1-4.

SILAN, Janko [ĎURKA, Ján], 1998. List Lacovi Novomeskému. In SILAN, Janko. Súborné dielo 8. Bratislava: Lúč, s. 117. ISBN 80-7114-237-9.

ST. S, 1947. Bát' sa alebo sa nebát'? Nová práca, roč. 3, č. 7-8, s. 507-508.

STANKOVSKÝ, Aloš [FS], 1946a. Ján Smrek: Studňa. Nová práca, roč. 2, č. 12-13, s. 204.

STANKOVSKÝ, Aloš [FS], 1946b. Marcel Horniak: Životné pramene krásneho písomníctva. Nová práca, roč. 2, č. 13, s. 205.

STANKOVSKÝ, Aloš [FS], 1946c. Pavol Bunčák: S tebou a sám. Nová práca, roč. 2, č. 14, s. 223.

STANKOVSKÝ, Aloš [FS], 1946d. Priznanie. Na 25. výročie Hviezdoslavovej smrti. Nová práca, roč. 2, č. 22, s. 348-349.

STANKOVSKÝ, Aloš [FS], 1946e. Štefan Krčméry: Pozdrav odmlčaného básnika. Nová práca, roč. 2 , č. 4 , s. 57.

STANKOVSKÝ, Aloš [FS], 1946f. Vladimír Reisel: Zrkadlo a za zrkadlom. Nová práca, roč. 2 , č. 9 , s. 142.

ŠTEBLÍK, Stanislav, 1947. Falšovat' dejiny literatúry? Nová práca, roč. 3, č. 2, s. 122.

VÁLEK, Miroslav, 1946. Ticho nad krajom. Nová práca, roč. 2, č. 15-16, s. 245.

VSTUPNÉ slovo, 1948. Verbum, roč. 2, č. 7-8, s. 369-370.

X, 1947. Proti komu útočí Dr. Matuška vo svojom Vajanskom? Verbum, roč. 1, č. 6-7, s. 329-330.

ZAWIEYSKI, Jerzy, 1947. Otázka katolíckej literatúry. Verbum, roč. 1, č. 10, s. 512-524

\section{Literatúra}

BALÚNOVÁ, Melánia-MIHÓKOVÁ, Mária-LUKÁČ, Rudolf, ed., 1995. Slovenská národná retrospektínna bibliografia. Séria B. Periodiká. Martin: Matica slovenská. ISBN 80-7090-320-1.

BÍLIK, René, 2013. Polemika o anjelských zemiach ako literárnohistorický problém. Slovenská literatúra, roč. 60, č. 5, s. 359-370. ISSN 0037-6973. 
BOMBÍKOVÁ, Petra, 1998. Verbum, časopis pre krestanskú kultúru 1946 - 1948. Slovenská literatúra, roč. 45, č. 3, s. 197-202. ISSN 0037-6973.

DRUG, Štefan, 1993. Pamätníci a archív o zániku časopisu Verbum. Slovenské pohlady, roč. 109 , č. 2, s. 86-96. ISSN 1335-7786.

DRUG, Štefan, 1999. Labutia pieseň vydavatela, redaktora a publicistu Elánu. Slovenská literatúra, roč. 46, č. 2, s. 129-134. ISSN 0037-6973.

FEDOR, Michal, 1992. Časopis Verbum (jeho miesto v našom kultúrnom kontexte). Viera $a$ život, roč. 2, č. 1, s. 44-51.

FRONC, Martin B., 1997. Koniec Verbumu. In Verbum. Zborník k 50. výročiu vzniku časopisu 1946 - 1996. Košice: Verbum, s. 54-56. ISBN 80-966957-6-2.

HANUS, Ladislav, 1943. Rozprava o kultúrnosti. Ružomberok: Obroda.

HANUS, Ladislav, 1992. Jozef Kútnik Šmálov. Poprad: Spišský kňazský seminár. ISBN 80-0142-005-0.

HARČAR, Anton, 1997. Poznámky ku genéze a zákazu časopisu Verbum. In Verbum. Zborník k50. výročiu vzniku časopisu 1946-1996. Košice: Verbum, s. 36-53. ISBN 80-966957-6-2.

JUHÁSOVÁ, Jana, 2018. Litanická forma od avantgardy po súčasnost'. Ružomberok: Verbum - Katolícka univerzita. ISBN 978-80-561-056-27.

KATUNINEC, Milan, 2005. Spolok svätého Vojtecha od konca druhej svetovej vojny po zmenu na „účelové zariadenie“ (1945 - 1954). Historický časopis, roč. 53, č. 2, s. 305-326. ISSN 0018-2575.

MARSINA, Richard - ČIČAJ, Viliam - KOVÁČ, Dušan - LIPTÁK, Lubomír, 1992. Slovenské dejiny. Martin: Vydavatel'stvo Matice slovenskej. ISBN 80-7090-239-6.

MATUŠKA, Alexander, 1956. Pre a proti. Bratislava: Slovenský spisovatel'.

MIKO, František: Polemika o ,anjelských krajinách“ a otázky realizmu v slovenskej próze štyridsiatych rokov. Slovenská literatúra, roč. 25, 1978, č. 1, s. 6-31. ISSN 0037-6973.

MOTULKO, Ján, 2002. L'udská tvár básnika. Za Alošom Stankovským. Kultúra, roč. 5, č. 2, s. 10. ISSN 1336-299.

MRÁZ, Andrej, 1948. Dejiny slovenskej literatúry. Bratislava: SAVU.

PRÍHODOVÁ, Edita, 2008. Dominanty literárnokritickej činnosti Jozefa Kútnika Šmálova. Slovenská literatúra, roč. 55, č. 6, s. 37-45. ISSN 0037-6973.

PRÍHODOVÁ, Edita, 2016. Kultúrna činnost' katolíckej cirkvi v Československu v rokoch 1945 - 1948. Kultúrne dejiny, roč. 7, č. 2, s. 257-287. ISSN 1338-2209.

PRÍHODOVÁ, Edita, 2020. Spievam, lebo milujem. Život a dielo Janka Silana. Bratislava: Literárne informačné centrum. ISBN 978-80-8119-127-5.

PUTNA, Martin C., 1998. Česká katolická literatura 1848 - 1918. Praha: Torst. ISBN 80-7215-059-6.

STANKOVSKÝ, Aloš, 1997. Verbum ako „časopis duchovnej aristokracie“. In Verbum. Zborník k 50. výročiu vzniku časopisu 1946 - 1996. Košice: Verbum, s. 97. ISBN 80-966957-6-2.

VAŠKO, Václav, 1990. Neumlčená kronika katolické církve v Československu po druhé světové válce. Praha: Zvon. ISBN 80-7113-035-4.

Mgr. Edita Prihodová, PhD.

Tarasa Ševčenka 9

08001 Prešov

Slovenská republika

E-mail: editacj@gmail.com 